\title{
Studies on solidification of wastes from metal coating
}

\author{
Kamil P. Banaszkiewicz, Tadeusz Marcinkowski \\ Wroclaw University of Technology, Institute of Environment Protection Engineering, Plac Grunwaldzki 9, 50-377 \\ Wroclaw, Poland
}

\begin{abstract}
There are over 1000 electroplating workshops functioning in Poland; they are agglomerated in automotive industry, agricultural and construction machines industry, precision instruments industry, electronics, electrotechnics, etc.. ${ }^{2}$. The chemical composition of wastes from galvanizing plants strictly depends on the technological processes as well as the methods of neutralization of industrial wastewaters. The wastes mentioned can be neutralized, among other possibilities, using cement, fly ashes or lime. The material that gains the widest applicability for treating a wide spectrum of hazardous wastes is Portland cement. Using cement enables an improvement of the physical (solidifying) and chemical characteristics of various kinds of wastes, that ensures a decrease in the mobility of contaminants (stabilization). The process using Portland cement (CEM I 32,5 R) was used towards galvanic sludges. The results presented in this article allow for the assesment of the applicability of mixture of cement with mortar sand, as well as the mixture of cement and flotation tailings for the stabilizing and solidifying galvanic sludge, containing mainly $\mathrm{Cr}, \mathrm{Cu}, \mathrm{Zn}$ and Ni. The presented study was also concentrated on the limitation in the transport of leached contaminants to the environment, the reduction of the solubility of hazardous contaminants, as well as a change in the physical structure of the waste - in other words, derivation of the product that could be mechanically durable during transport and storage.
\end{abstract}

Keywords: stabilization/solidification, portland cement, sand, flotation tailings, galvanic sludges, heavy metals.

Presented at VII Conference Wasteless Technologies and Waste Management in Chemical Industry and Agriculture, Międzyzdroje, 12 - 15 June, 2007.

\section{INTRODUCTION}

Galvanic sludge, due to presence of toxic metals, is classified in group 11 or 19 by Polish regulations, and is regarded as hazardous waste. It is in accordance with the instruction of The Minister of Environment, concerning the catalogue of wastes ${ }^{3}$. It is quite common, all over the world, to use the process of stabilization/solidification (S/ S) to neutralize hazardous wastes. Such techniques were used in the USA, in the fifties of the previous century, initially for processing the radioactive waste, and since the early seventies they have been quite commonly used for the treatment of industrial hazardous waste ${ }^{8}$. S/S technologies are categorized by U.S. EPA as the best documented technologies available for 57 kinds of hazardous wastes ${ }^{13}$. The basic material employed in the process of $\mathrm{S} /$ $\mathrm{S}$ is Portland cement, often joined with other constructional/mineral binding factors, such as fly ashes, blast furnace slags, quick or hydrated lime, as well as liquid glass that is used as a material improving solidification and concretion ${ }^{11}$. The effectiveness of waste treatment process gets out of interactions between these materials and the components of waste being stabilized or solidified $^{1,11,12}$. The processes of stabilization and solidification proceed concurrently and produce better character- istics of treated material in terms of mechanical strength, and at the same time pollutants are chemically bound to the forms that are less mobile and less toxic ${ }^{8,13}$. This study presents the results of our own research on the neutralization of galvanic wastes.

\section{MATERIALS}

Galvanic sludge came from all kinds of galvanic coating processes, had semi-solid consistency, was characterized by dark-green colour and its hydratation was from 71.40 to $74.20 \mathrm{H}_{2} \mathrm{O}$. Table 1 presents the analysis of metal concentrations in raw sludge and in eluates from extractions with: a) distilled water of the $\mathrm{pH} 6.33$; b) the solution of the $\mathrm{pH} 3.00$; and c) the solution of the $\mathrm{pH} 11.50$. Very high concentrations of chromium, zinc, copper and nickel, accordingly, $89540 \mathrm{mg} / \mathrm{kg}, 85470 \mathrm{mg} / \mathrm{kg}, 73260$ $\mathrm{mg} / \mathrm{kg}$ and $9158 \mathrm{mg} / \mathrm{kg}$ - confirmed that the examined sludge could be categorized as a hazardous waste ${ }^{6}$. Among the concentrations of selected contaminants in eluates, these for $\mathrm{Cu}$ and $\mathrm{Ni}$ exceeded the acceptable concentrations for the treated industrial wastes ${ }^{4}$. The $\mathrm{pH}$ of the eluates obtained in the contaminants leaching tests for the solution (A) of the initial $\mathrm{pH}$ of 3.00 was 6.59 ; for the solution (B) of the initial pH of 11.50 it was 7.09.

Table 1. The concentrations of metals in the examined galvanic sludge

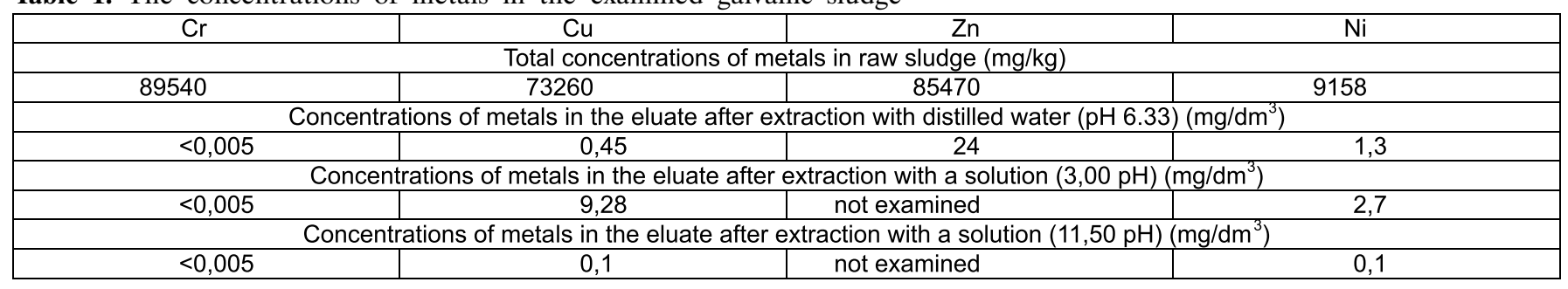


Table 2. The concentrations of the metals used in the flotation tailings

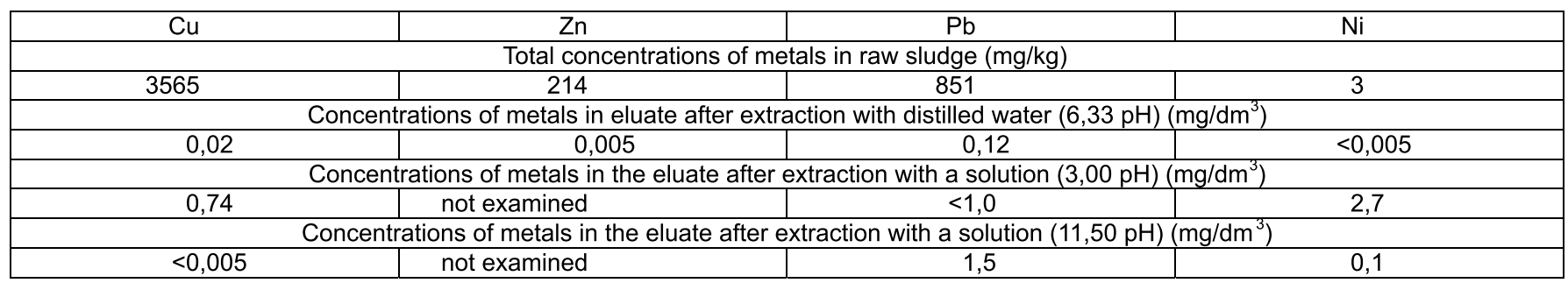

Table 3. The chemical composition of the solutions obtained in the TCLP test

\begin{tabular}{|c|c|c|c|c|c|c|}
\hline & Proportion & $\begin{array}{l}\text { Leaching solution A } \\
\mathrm{mg} / \mathrm{dm}^{3}\end{array}$ & $\begin{array}{l}\text { Leaching solution B } \\
\mathrm{mg} / \mathrm{dm}^{3}\end{array}$ & $\begin{array}{l}\text { Acceptable value } \\
\mathrm{mg} / \mathrm{dm}^{3}\end{array}$ & $\begin{array}{c}\mathrm{pH} \text { of eluate } \\
\text { Leaching solution } \mathrm{A} \\
\end{array}$ & $\begin{array}{c}\mathrm{pH} \text { of eluate } \\
\text { Leaching solution } \mathrm{B}\end{array}$ \\
\hline \multicolumn{7}{|c|}{ Sludge/Cement } \\
\hline \multirow[t]{3}{*}{$2 / 1$} & Chromium (Cr) & 6,15 & 6,52 & 0,5 & \multirow{3}{*}{11,59} & \multirow{3}{*}{12,00} \\
\hline & Copper (Cu) & 0,69 & 1,23 & 0,5 & & \\
\hline & Nickel (Ni) & 0,04 & 0,08 & 0,5 & & \\
\hline \multirow[t]{3}{*}{$4 / 1$} & Chromium (Cr) & 1,58 & 1,8 & 0,5 & \multirow{3}{*}{8,72} & \multirow{3}{*}{10,60} \\
\hline & Copper (Cu) & 0,11 & 0,27 & 0,5 & & \\
\hline & Nickel $(\mathrm{Ni})$ & 0,24 & 0,16 & 0,5 & & \\
\hline \multicolumn{7}{|c|}{ Sludge/Sand/Cement } \\
\hline \multirow[t]{3}{*}{$2 / 1 / 1$} & Chromium (Cr) & 6,11 & 5,88 & 0,5 & \multirow{3}{*}{11,54} & \multirow{3}{*}{11,97} \\
\hline & Copper (Cu) & 0,42 & 0,56 & 0,5 & & \\
\hline & Nickel (Ni) & 0,15 & 0,04 & 0,5 & & \\
\hline \multirow[t]{3}{*}{$3 / 1 / 0,5$} & Chromium (Cr) & 0,36 & 0,68 & 0,5 & \multirow{3}{*}{7,77} & \multirow{3}{*}{9,53} \\
\hline & Copper (Cu) & 0,02 & 0,1 & 0,5 & & \\
\hline & Nickel (Ni) & 0,11 & 0,13 & 0,5 & & \\
\hline \multirow[t]{3}{*}{$3 / 1 / 1$} & Chromium (Cr) & 2,57 & 3,94 & 0,5 & \multirow{3}{*}{10,62} & \multirow{3}{*}{11,50} \\
\hline & Copper (Cu) & 0,56 & 0,62 & 0,5 & & \\
\hline & Nickel (Ni) & 0,24 & 0,22 & 0,5 & & \\
\hline \multirow[t]{3}{*}{$4 / 1 / 1$} & Chromium (Cr) & 0,88 & 1,31 & 0,5 & \multirow{3}{*}{8,17} & \multirow{3}{*}{10,57} \\
\hline & Copper (Cu) & 0,1 & 0,2 & 0,5 & & \\
\hline & Nickel (Ni) & 0,06 & 0,12 & 0,5 & & \\
\hline \multicolumn{7}{|c|}{ Sludge/Flotation sludge/Cement } \\
\hline \multirow[t]{4}{*}{$3 / 1 / 0,5$} & Chromium (Cr) & 0,25 & 0,46 & 0,5 & \multirow{4}{*}{8,20} & \multirow{4}{*}{10,52} \\
\hline & Copper (Cu) & 0,1 & 0,05 & 0,5 & & \\
\hline & Nickel $(\mathrm{Ni})$ & 0,28 & 0,18 & 0,5 & & \\
\hline & Lead $(\mathrm{Pb})$ & 0,29 & 0,34 & 0,5 & & \\
\hline \multirow[t]{4}{*}{$3 / 1 / 1$} & Chromium (Cr) & 2,24 & 3,04 & 0,5 & \multirow{4}{*}{11,16} & \multirow{4}{*}{11,62} \\
\hline & Copper (Cu) & 0,98 & 0,84 & 0,5 & & \\
\hline & Nickel $(\mathrm{Ni})$ & $<0,01$ & 0,04 & 0,5 & & \\
\hline & Lead $(\mathrm{Pb})$ & 0,25 & 0,21 & 0,5 & & \\
\hline \multirow[t]{4}{*}{$4 / 1 / 1$} & Chromium (Cr) & 0,81 & 1,49 & 0,5 & \multirow{4}{*}{7,94} & \\
\hline & Copper (Cu) & 0,14 & 0,39 & 0,5 & & \\
\hline & Nickel (Ni) & 0,27 & 0,34 & 0,5 & & 10,37 \\
\hline & Lead $(\mathrm{Pb})$ & 0,26 & 0,23 & 0,5 & & \\
\hline
\end{tabular}

Flotation tailings. The examined material was powdery, grey and of very low hydratation -7.34 . The silica content that constitutes $80.23 \%$ of the waste mass the reason of using flotation tailings as a substitute of mortar sand. Table 2 presents the analysis of the concentrations in untreated flotation tailings from copper ores mine and in the eluates obtained from extraction with the solutions (A) of $\mathrm{pH} 3.00$ and (B) of $\mathrm{pH} 11.50$. The concentrations of particular metals were as follows: copper $-3565 \mathrm{mg} /$ $\mathrm{kg}$, zinc $-214 \mathrm{mg} / \mathrm{kg}$, lead $-851 \mathrm{mg} / \mathrm{kg}$ and nickel $-3 \mathrm{mg} /$ $\mathrm{kg}$. The $\mathrm{pH}$ of the eluate obtained in contaminants leaching tests for the solution (A) of the initial $\mathrm{pH} 3.00$ was 8.70; for the solution (B) of initial $\mathrm{pH} 11.50$ it was 9.22. In the eluates from contaminants leaching tests only $\mathrm{Pb} \mathrm{i}$ $\mathrm{Cu}$ insignificantly exceeded the acceptable concentrations for the treated industrial wastewater $\left(0.5 \mathrm{mg} / \mathrm{dm}^{3}\right)^{4}$.
Other materials used as determinative factors in the process of stabilization and solidification were the already mentioned Portland cement CEM I 32.5 R and mortar sand, modification I'.

\section{METHODOLOGY OF SOLIDIFICATION}

In the conducted experiments galvanic sludge was neutralized using: a) Portland cement only; b) a mixture of cement and mortar sand, and c) a mixture of cement and flotation tailings from the copper ore mine. In all the cases water was added in the volume dependent on the consistency of the mixture. All the components were mixed together for $180 \mathrm{~s}$ in a special reactor - Tecnotest B205/ X5 mixer. The obtained mixture was poured into cylindrical forms (diameter and height of $8 \mathrm{~cm}$ ) and thickened on a vibrating table for $300 \mathrm{~s}$. After 3 days of concretion, the 


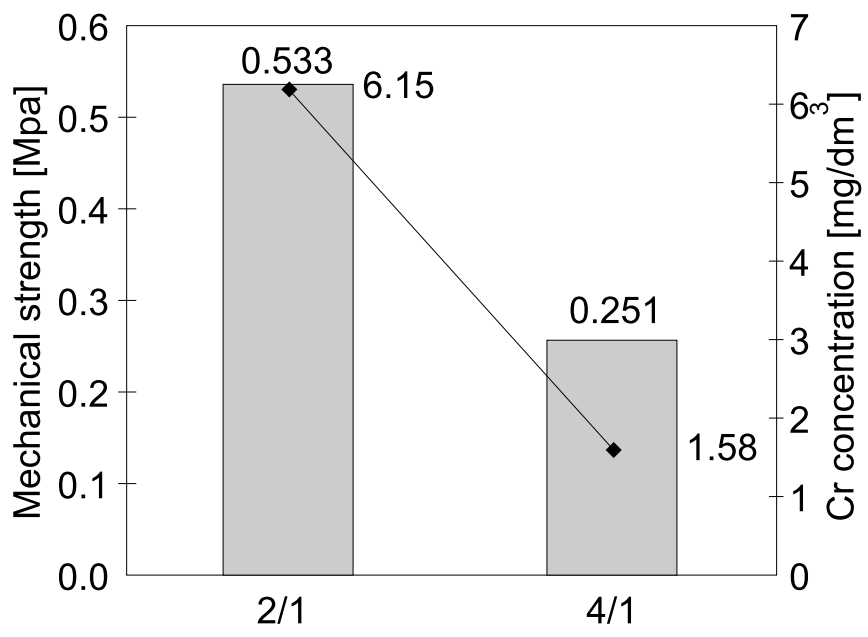

Axial compression strength

$\mathrm{Cr}$ concentration in eluate from

extraction with solution, $\mathrm{pH}=3.00$

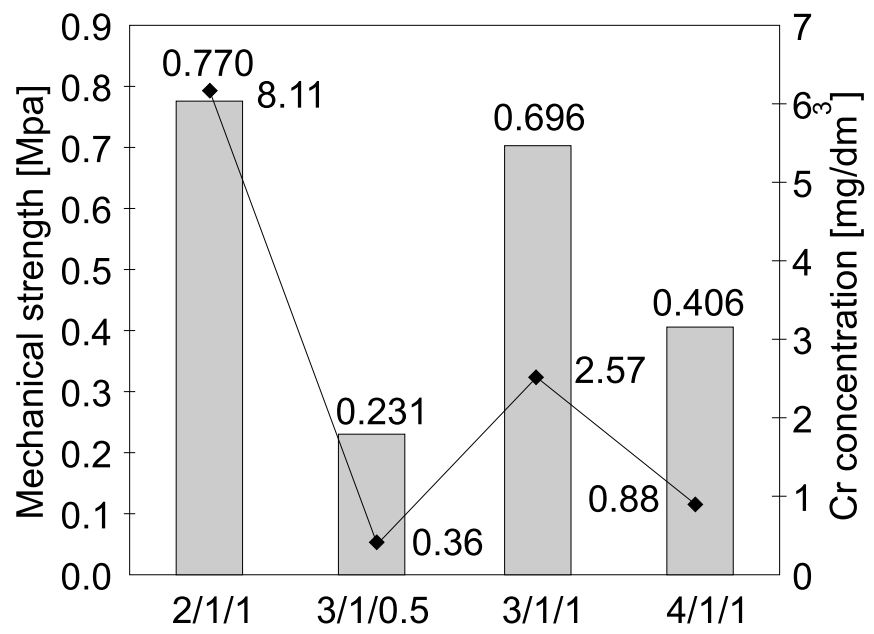

Axial compression strength

- $\mathrm{Cr}$ concentration in eluate from extraction with solution, $\mathrm{pH}=3.00$

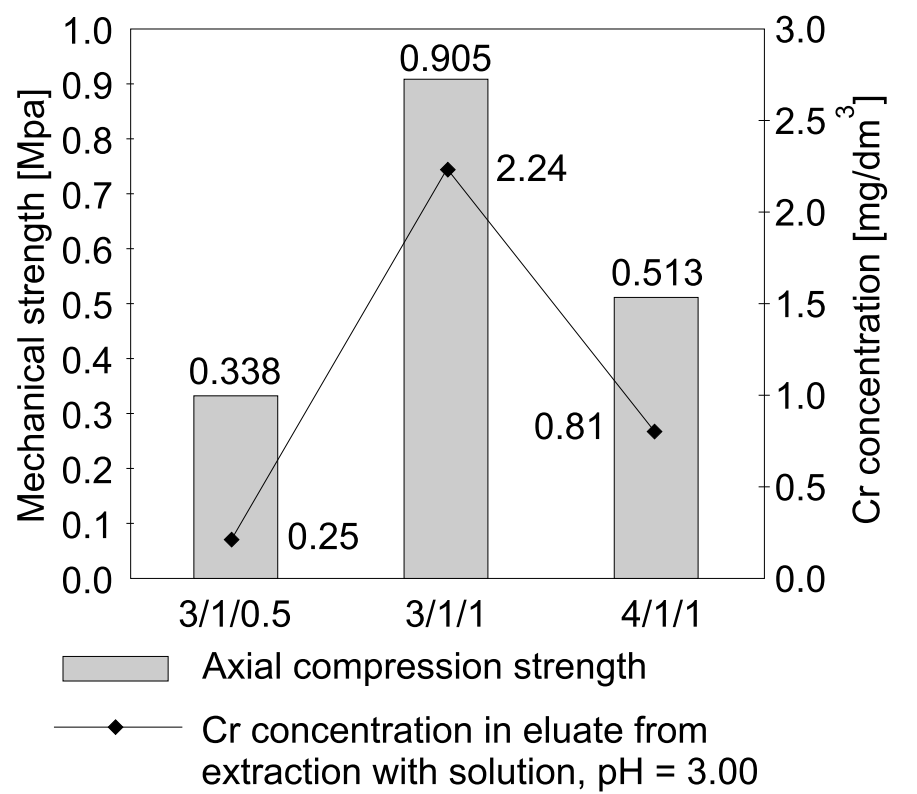

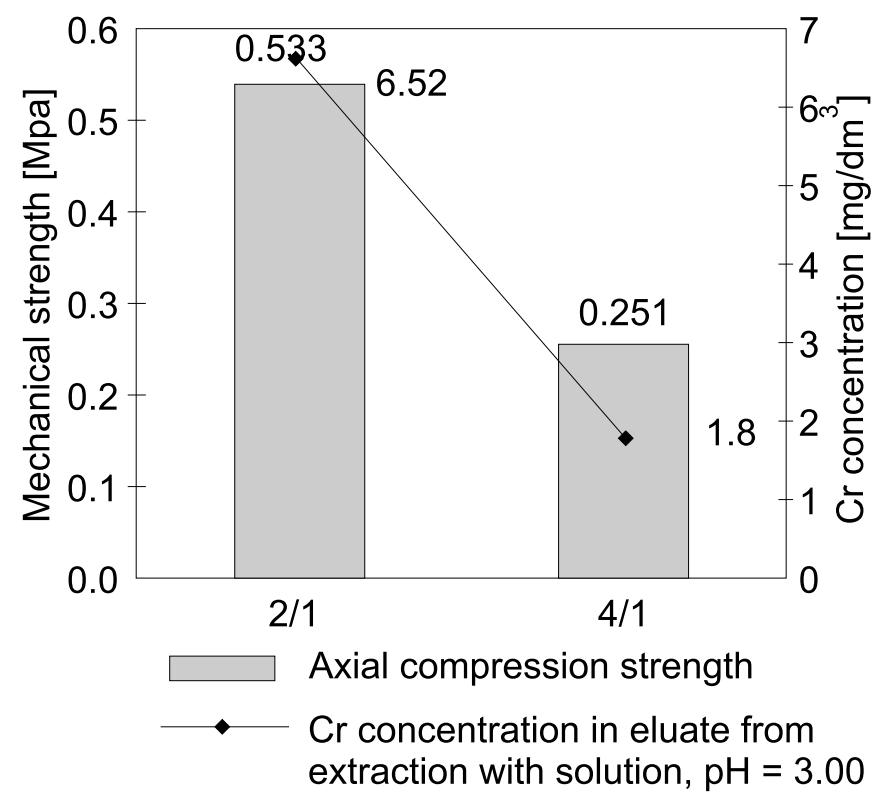
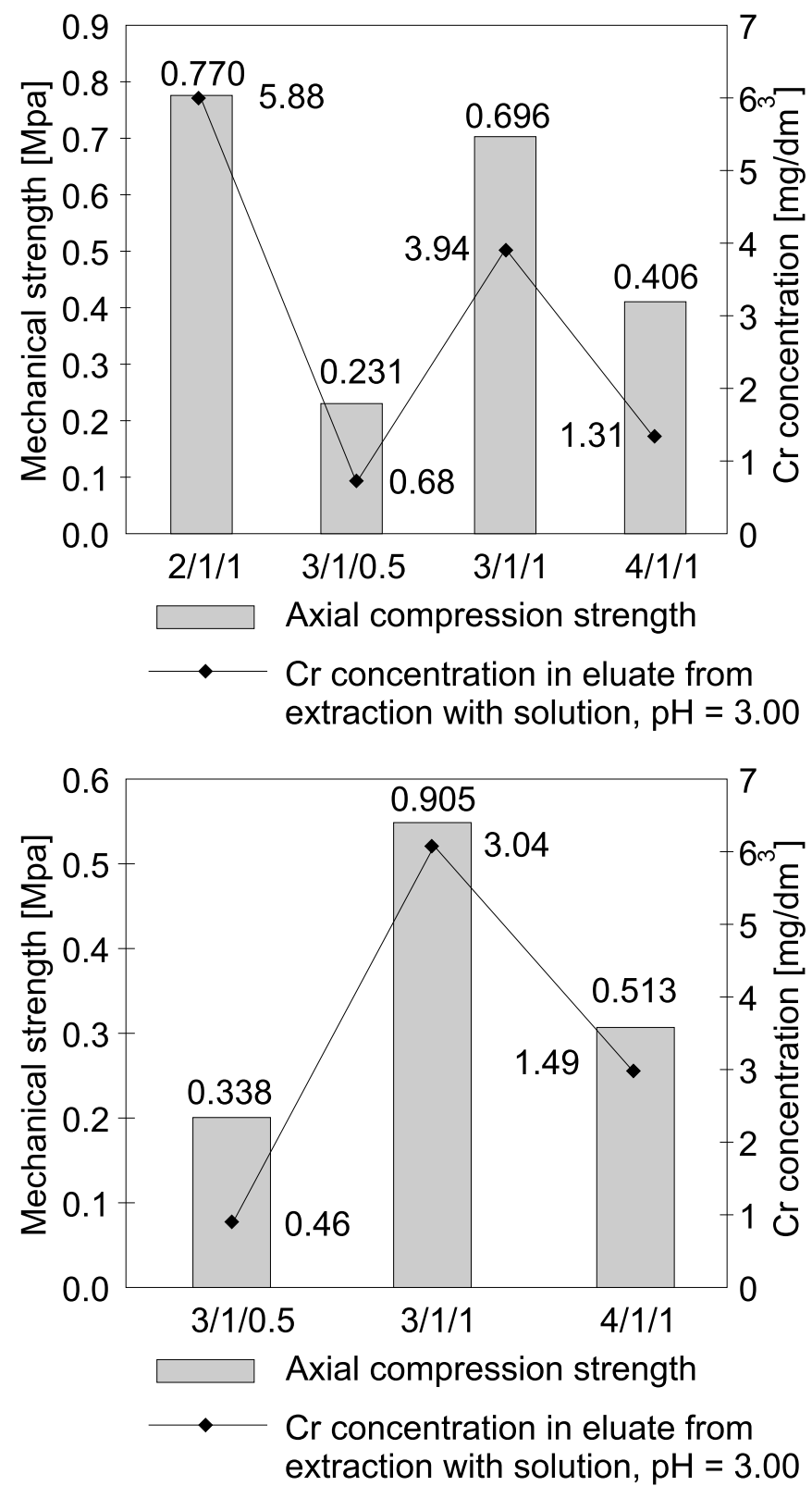

Figure 1. The concentration of chromium in the lye from the extraction with the solutions having the $\mathrm{pH}$ of 3.00 and 11.50 


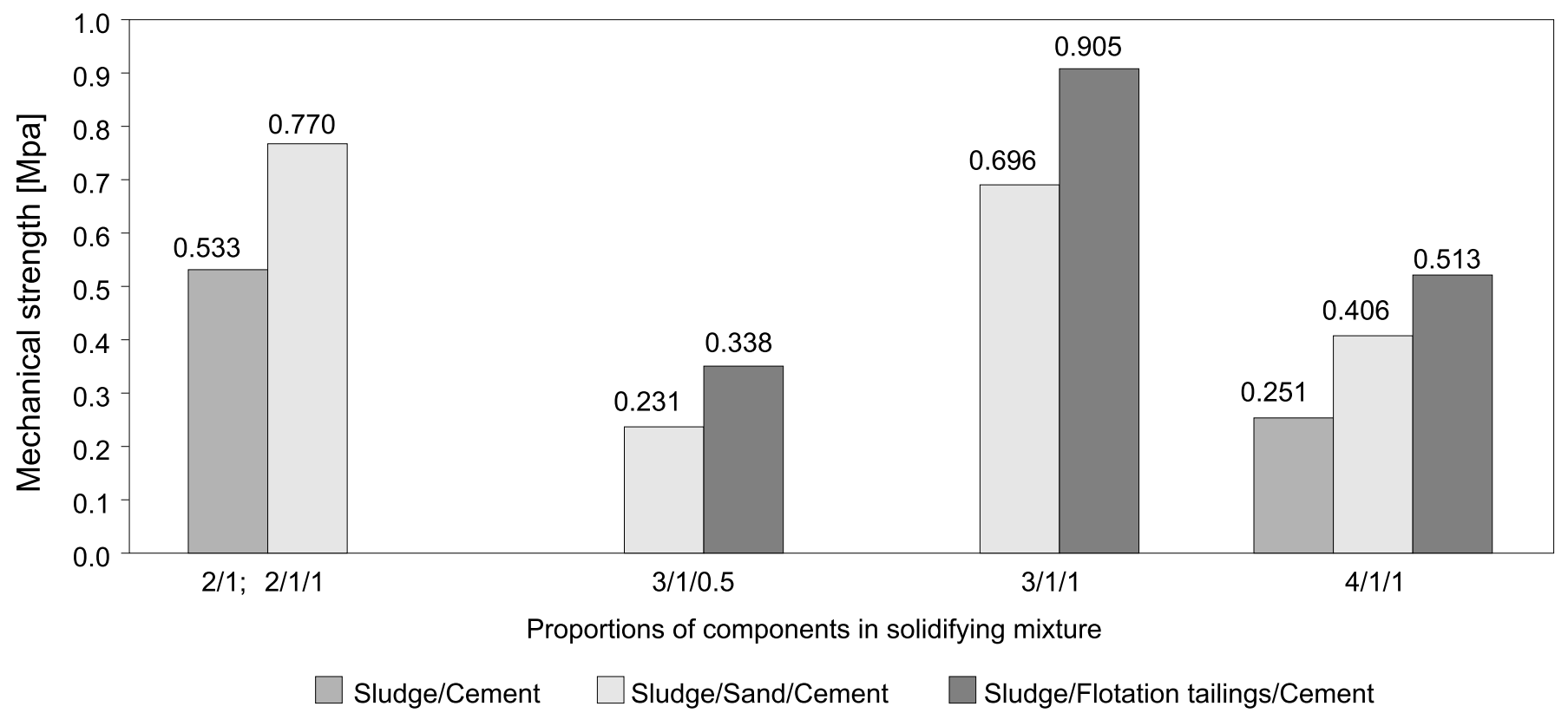

Figure 2. Changes in axial mechanical compression strength of the solidified samples due to the quantitative proportions of the fixing mixture components

samples were disintegrated and left for the next 25 days at the temperature of $23^{\circ} \mathrm{C}$ and the humidity of $60 \%$, a period of maturation.

\section{LEACHING OF CONTAMINANTS FROM SOLIDIFIED SAMPLES}

The contaminants leaching test was performed for raw sludge as well as for the solidified samples. A sample of the material examined was disintegrated to the granulation below $1 \mathrm{~cm}$, poured with the leaching solutions (A) of $\mathrm{pH} 3.00$ and (B) of $\mathrm{pH} 11.50$ with the proportion liquid/dry mass of 10/1 and shaken in a shaker for $24 \mathrm{~h}$. The obtained eluates were then filtered and analyzed for the content of the selected metals. Besides, for comparison, extraction of raw sludges with distilled water (control samples) was performed.

Table 3 presents the results of the leaching tests from solidified samples. The $\mathrm{pH}$ of the lye from both solutions varied from 7.77 to 12.00 . The only sample complying to the chemical requirements due to chromium content ${ }^{4}$ was the sample of the following proportions: sludge/flotation tailings/cement $=3 / 1 / 0.5$. In all other eluates the concentration of chromium exceeded the acceptable value and was singnificantly higher than in the leaching solution obtained from leaching raw waste. Besides, the extent of leaching copper and nickel did not exceed the acceptable values ${ }^{4}$. Figure 1 presents the changes in chromium concentration in the extracts from the contaminants leaching tests, as well as the results of axial compression tests.

\section{EVALUATION OF THE MECHANICAL STRENGTH OF THE SOLIDIFIED SAMPLES}

Examinations of the solidified waste samples were prepared in accordance with the standard procedure required for mechanical strength tests. After 28 days of maturation the measurements of mechanical strength were performed, in compliance with a valid method of compression strength of cylindrical samples ${ }^{\mathbf{1 0}}$. The examination was performed on the testing machine with an appropriate range of forces
(Tecnotest KD 150/30E). Each measurement was taken for 3 identical samples, and the results presented in Figure 2 are mean values.

In accordance with the U.S. Environmental Protection Agency guidelines, the solidified samples must meet the conditions of minimal compression strength that is established as $0.345 \mathrm{MPa}^{7}, 11,12$. According to Polish legislation, $0.5 \mathrm{MPa}^{5}$ is the minimal axial compression strength.

The compression strength of the samples, measured after 28 days, was decreasing with the increasing amounts of the galvanic sludge added. The final product having the proportion of sludge/cement $=2 / 1$, had the compression strength at the level of $0.533 \mathrm{MPa}$, but in the sample of the sludge/cement $=4 / 1$ proportion, the compression strength was lowered to $0.251 \mathrm{MPa}$. In the samples that had mortar sand added as an addition, in the same quantity as with the cement dose, a significant gain of compression strength was observed. A monolith having a composition of sludge/sand/ cement $=4 / 1 / 1$ had a compression strength at the level of $0.406 \mathrm{MPa}$. The final product, demonstrating the proportions of the sludge/flotation tailings/cement $=4 / 1 / 1 \mathrm{had}$ a compression strength of 0.513 $\mathrm{MPa}$, and the total waste material accounted for over $83 \%$ of the sample mass.

\section{SUMMARY}

The measurements of axial compression strength taken after 28 days showed that the solidification of galvanic sludge with cement as the sole fixing agent gives worse results than the solidification with a mixture of cement and sand or a mixture of cement and flotation tailings. The requirements of Polish legislation in relation to the minimal axial compression strength ${ }^{5}$ are fulfilled by the samples solidified with the following proportions: sludge/ cement $=2 / 1$; sludge $/$ sand $/$ cement $=2 / 1 / 1,3 / 1 / 1$ and $4 /$ $1 / 1$; as well as the sludge/flotation tailings/cement $=3 / 1$ / 1 and 4/1/1. The chemical requirements concerning the acceptable content of the selected metals $(\mathrm{Cr}, \mathrm{Cu}, \mathrm{Ni}, \mathrm{Pb}$ $\left.=0.5 \mathrm{mg} / \mathrm{dm}^{3}\right)^{4}$ examined in both eluates obtained, are 
fulfilled by a monolith with the following composition: sludge/ flotation tailings/cement $=3 / 1 / 0.5$. However, this sample did not meet the condition of the minimal mechanical compression strength.

\section{LITERATURE CITED}

(1) Batchelor B.: Overview of waste stabilization with cement. Waste Management 26, 689 - 698. Elsevier Inc., 2006.

(2) GUS: Ochrona środowiska 2005. Departament Statystyki Rolnictwa i Środowiska. Warszawa, 2005.

(3) Dziennik Ustaw nr 112, Poz. 1206: Rozporządzenie Ministra Środowiska z dnia 27 września 2001 r. w sprawie katalogu odpadów.

(4) Dziennik Ustaw nr 168, Poz. 1763: Rozporządzenie Ministra Środowiska z dnia 8 lipca 2004 r. w sprawie warunków, jakie należy spełnić przy wprowadzaniu ścieków do wód lub do ziemi, oraz w sprawie substancji szczególnie szkodliwych dla środowiska wodnego.

(5) Dziennik Ustaw nr 186, Poz. 1552 i 1553: Rozporządzenie Ministra Gospodarki i Pracy z dnia 7 września 2005 r. w sprawie kryteriów oraz procedur dopuszczania odpadów do składowania na składowisku odpadów danego typu.

(6) Magalhaes M., Silva E., Castro P., Labrincha A.: Phisical and chemical characterisation of metal finishing industrial wastes, Journal of Environmental Management, 2005, 72, $157-166$.

(7) Paria S., Yuet P. K.: Solidification/Stabilization of Organic and Inorganic Contaminants using Portland Cement: A Literature Review. Published in Environmental Reviews, Vol 14, P 217 - 255, 2006.

(8) Spence R. D., Shi C.: Stabilization and Solidification of Hazardous, Radioactive, and Mixed Wastes. CRC Press, 2005.

(9) Stefańczyk B. i inni: Budownictwo ogólne ,materiały i wyroby budowlane, tom 1, Wydawnictwo Arkady, Warszawa 2005.

(10) Śliwiński J., Gonciarz B., Luchter-Marchewka E., Tracz T., Zych T.: „Materiały budowlane - ćwiczenia laboratoryjne”, Politechnika Krakowska, 2001.

(11) U.S. EPA HAZCON Solidification Process, Douglassville, PA. Application Analysis Report. EPA/540/A589/001, Office of Research and Development, Cincinnati $\mathrm{OH}, 1989$.

(12) U.S. EPA SILICATE TECHNOLOGY CORPORATION'S. Solidification/Stabilization Technology for Organic and Inorganic Contaminants in Soils. Application analysis report. EPA/540/AR-92/010, Office of Research and Development, Cincinnati OH, 1992.

(13) Woodart F. E., Curran F.: Industrial Waste Treatment Handbook. Second Edition. Elsevier Inc., 2006. 